\title{
Opportunities and Boundaries of Transport Network Telematics
}

\author{
Simone Porru, Filippo Eros Pani, Cino Repetto, Francesco Edoardo Misso \\ T Bridge \\ via Garibaldi 7/10, Genova, Italy \\ s.porru@tbridge.it; f.pani@tbridge.it; c.repetto@tbridge.it; f.misso@tbridge.it
}

\begin{abstract}
Demographic changes in peripheral areas pose serious challenges on regional public transport systems. Recently, the response to such pressures has led to evaluate Internet of Things (IoT) technologies as a means to tackle mobility challenges in rural areas, thus leading to the concept of smart land. The urban areas usually provide suitable conditions for the successful application of IoT technologies, as proven by the successful outcome of several smart city projects. Framed within the context of the INTERREG Central Europe project RUMOBIL, this paper's main goal is to understand whether it is possible to successfully deploy smart mobility systems on the rural context as it is on the urban context. To this aim, on the basis of a comprehensive literature review, we compared the ease of implementation of different IoT solutions on the urban and the rural context for planners, travellers, and operators, and, also, the degree of complexity of common smart mobility issues in both the urban and the rural context. Indeed, the novelty of this study resides in the comparison of the opportunities' feasibility and challenges' complexity of the application of IoT technologies to rural and urban mobility solutions. We found that both smart cities and smart lands are suitable to benefit from smart mobility solutions. Even considering the different levels of population scattering, technological infrastructures, social maturity, and economic opportunities, both rural and urban areas offer comparable advantages.
\end{abstract}

Keywords: Smart Mobility, Iot, Transport Services, Smart City, Smart Land.

\section{Introduction}

This paper has been developed under the INTERREG Central Europe project "RUMOBIL" to identify the opportunities provided by the use of networked telematics ("Internet of things", IoT) for the improvement of the quality of public transport services, and to define the boundaries of the applications of such systems on public transport in peripheral areas. More specifically, the study serves as an input to the definition of a strategy addressing the development of sustainable public transport in rural areas, thus contributing to the RUMOBIL main goal of promoting sustainable mobility in rural areas.

The adopted transnational strategy presents to central Europe regions innovative and transferable public transport approaches on the basis of jointly analysed good practices, the combined knowledge of the partners and involved stakeholders, lessons learned from the pilots, and fresh ideas put forward through a transnational social media-based competition. The strategy outline includes the mobility needs in rural and peripheral areas, collected and analysed starting from, among others, scientific literature, technical visits, and best practices, together with the solutions that could be applied to resolve or reduce the critical points. To be managed and improved, these actions and solutions need to retrieve and process information. Thanks to the IoT technologies [1] [2], information collection and analysis are easier and more effective, because these operational steps are accomplished directly by the "things" and devices included in the information flow network [3] [4].

Innovation opportunities enabled by IoT technologies are often associated with an urban context, i.e. with the concept of smart city. However, the final scope of this paper is to show if and how the quality of rural transport systems can be improved through the implementation of such pervasive technologies. More specifically, the research question for this review is:

RQ1. Does only a urban environment provide suitable conditions for the successful application of IoT technologies, or can we imagine a smart mobility system for a smart land too [5]?

The document is structured as follows: in Section 1, we frame the context of our study and define the research question; in Section 2, we describe which opportunities are enabled by smart mobility; in Section 3, we describe the 
research methodology; in Section 4, we provide details about 8 relevant smart mobility projects identified through the literature review; in Section 5, we present our conclusion.

\section{Opportunities of Smart Mobility}

Smart Mobility is deeply connected to sustainable mobility, and thus promotes and supports higher life quality [6]. Nowadays, huge amounts of real-time data can be processed and used to optimize the urban infrastructure, thereby making public transport services more efficient from both the final user's and the service provider's perspective. Location-based data analysis allows for identifying the most useful services for citizens at a certain time.

Compared to other cities in the world, European ones boast better public transport services and are usually more committed to promote sustainability and low-carbon solutions. However, there is still room for improvement at a European level aiming at a decrease of pollution and carbon dioxide emissions. Plans to restrict traffic and parking in downtown areas have already started in several European cities with interruption of the production of industrial plants, or via speed limitations to reduce the current high levels of carbon dioxide output.

In the report for the Sustainable Mobility Project 2.0 [7], the authors described 22 indicators for parameters and methodologies to be used by cities to identify their sustainable mobility performance. Several of the identified indicators are also relevant to smart urban mobility (e.g., congestion and delays, mobility space usage, comfort and pleasure, traffic safety), which also tries to find synergies between a range of technologies such as vehicle manufacturing, transport information systems, communications technologies and logistics.

The evolution fostered by IoT applications will make different types of data collection easier, more accurate, and in real-time. Moreover, new types of remote control and automation will be devised. These developments bring about new opportunities for nearly all aspects of public transport, which can be classified based on the main beneficiaries, such as transport planners, operators, and travellers, as reported in [8].

\section{Research Methodology}

The study's main goal is to evaluate whether IoT technologies can lead to successful mobility solutions in rural areas, and also to provide an overview on the IoT state of the art, focusing on innovative applications of the IoT technologies on transportation. State-of-the-art tools and solutions reported in this document are intended to provide the information needed to forecast how demand for public transport will develop in coming years.

We have addressed RQ1 by comparing the smart mobility solutions for both rural and urban scenarios presented in Section 4, and the opportunities and issues related to smart mobility, as identified through the literature review, when they are considered from the perspective of a rural or an urban mobility solution.

In order to effectively identify the opportunities and issues created by the use of the Internet of Things to improve public transport quality, and to identify innovative solutions for the public transport in rural and urban areas, we selected publicly available material related to smart mobility. More specifically, we considered scientific literature and companies' reports relevant to IoT and smart mobility, and the official websites and publications regarding both ongoing and closed projects relevant to smart mobility. On the basis of the literature examined, we compared the ease of implementation of different IoT solutions and the related opportunities identified in [8] on an urban and rural context for planners, travellers, and operators; moreover, we also compared the degree of complexity of common smart mobility issues in both the urban and rural context [9].

\section{Smart Mobility Projects}

In this section we present a set of projects concerning IoT applications on mobility, which served to support our evaluation and comparison of the opportunities in Section 5. Such projects were selected as particularly relevant for the RUMOBIL project, as all of them include European pilot sites, part of them are dedicated solutions for rural areas, are fairly recent if not yet concluded, and most received considerable funding (several million euros). Table 1 presents a summary of the main features of each project. 
Table 1: Main features of relevant smart mobility projects.

\begin{tabular}{|c|c|c|c|c|}
\hline Project & Led by & Context & Description & Pilot Sites \\
\hline $\begin{array}{l}\text { COMPASS4D } \\
\text { Jan } 2013-\text { Dec } \\
2015\end{array}$ & ERTICO & $\begin{array}{l}\text { Cooperative } \\
\text { Intelligent } \\
\text { Transport } \\
\text { Systems }\end{array}$ & $\begin{array}{l}\text { Compass4D focused on three services aiming at increasing } \\
\text { drivers' safety and comfort by reducing the number and } \\
\text { severity of road accidents, by optimising the vehicle speed at } \\
\text { intersections and by avoiding queues and traffic jams. } \\
\text { COMPASS4D leverages technologies such as } 3 \mathrm{G} / \mathrm{LTE} \text {, on- } \\
\text { board units (OBUs) and road-side units (RSUs) based on } \\
\text { dedicated short-range communication technologies (ITS-G5). }\end{array}$ & $\begin{array}{l}\text { Newcastle, } \\
\text { Copenhagen, } \\
\text { Helmond, Verona, } \\
\text { Bordeaux, Vigo, } \\
\text { Thessaloniki }\end{array}$ \\
\hline $\begin{array}{l}\text { MOBiNET } \\
\text { Nov } 2012-\text { Jun } \\
2017\end{array}$ & $\begin{array}{l}\text { Rasmus } \\
\text { Lindholm, } \\
\text { ERTICO } \\
\text { ITS Europe }\end{array}$ & $\begin{array}{l}\text { e-marketplace } \\
\text { for mobility } \\
\text { services }\end{array}$ & $\begin{array}{l}\text { MOBiNET envisages a new "Internet of Mobility" which } \\
\text { would open the door to harmonised transport services, } \\
\text { seamless connectivity, instant access to transport data, single } \\
\text { subscription and billing for travellers and a one-stop shop for } \\
\text { mobility services. }\end{array}$ & $\begin{array}{l}\text { Aalborg, } \\
\text { Helmond, } \\
\text { Helsinki, London, } \\
\text { Torino, Trikala, } \\
\text { Trondheim, Vigo }\end{array}$ \\
\hline $\begin{array}{l}\text { TEAM } \\
\text { Nov } 2012-\text { Oct } \\
2016\end{array}$ & & $\begin{array}{l}\text { Collaboration } \\
\text { between } \\
\text { travellers, } \\
\text { drivers, and } \\
\text { road } \\
\text { infrastructure } \\
\text { operators }\end{array}$ & $\begin{array}{l}\text { TEAM (Tomorrow's Elastic Adaptive Mobility) turns } \\
\text { mobility from static into elastic by joining drivers, travellers } \\
\text { and infrastructure operators together into one collaborative } \\
\text { network. TEAM uses mobile devices such as smartphones to } \\
\text { significantly improve transportation safety and efficiency, } \\
\text { implementing environmental aspects. }\end{array}$ & $\begin{array}{l}\text { Berlin, } \\
\text { Gothenburg, } \\
\text { Tampere, Turin, } \\
\text { Trento, Athens, } \\
\text { Trikala }\end{array}$ \\
\hline $\begin{array}{l}\text { Array of Things } \\
2013 \text { - n.d. }\end{array}$ & $\begin{array}{l}\text { Argonne } \\
\text { National } \\
\text { Laboratory }\end{array}$ & Urban sensing & $\begin{array}{l}\text { AoT is an urban sensing project, a network of interactive, } \\
\text { modular sensor boxes that will be installed to collect real-time } \\
\text { data on a city's environment, infrastructure, and activity for } \\
\text { research and public use. AoT will provide real-time, location- } \\
\text { based data about a city's environment, infrastructure and } \\
\text { activity to researchers and the public }\end{array}$ & $\begin{array}{l}\text { Detroit, Denver, } \\
\text { Seattle, Portland, } \\
\text { Syracuse, Chapel } \\
\text { Hill, and several } \\
\text { other cities outside } \\
\text { the United States. }\end{array}$ \\
\hline $\begin{array}{l}\text { oneTRANSPOR } \\
\text { T}^{\mathrm{TM}} \\
2014-2026\end{array}$ & $\begin{array}{l}\text { InterDigital } \\
\text { Europe }\end{array}$ & Smart city & $\begin{array}{l}\text { The oneTRANSPORT Data Marketplace is an open, } \\
\text { standards-based environment that both public and private } \\
\text { sector organizations are using to publish their data, where it } \\
\text { can be discovered, consumed and used in any kind of } \\
\text { application or service. }\end{array}$ & UK-based \\
\hline $\begin{array}{l}\text { Informed Rural } \\
\text { Passenger } \\
2013-2014\end{array}$ & $\begin{array}{l}\text { Univ. of } \\
\text { Aberdeen }\end{array}$ & Rural transport & $\begin{array}{l}\text { Informed Rural Passenger aims at creating a transport } \\
\text { information ecosystem within which it is possible to explore } \\
\text { issues such as data provenance, reliability of passenger- } \\
\text { sourced information, and travel behaviour change. }\end{array}$ & UK-based \\
\hline $\begin{array}{l}\text { Social Journeys } \\
\text { Date: } \text { n.d. }\end{array}$ & $\begin{array}{l}\text { Univ.of } \\
\text { Aberdeen }\end{array}$ & Rural transport & $\begin{array}{l}\text { The project explores how social media updates can be } \\
\text { combined with existing (open) datasets to further enhance } \\
\text { real-time passenger information. }\end{array}$ & UK-based \\
\hline $\begin{array}{l}\text { on-the-go-rural } \\
\text { mobility } 2.0 \\
\text { Jan } 2016-\text { Dec } \\
2016 \\
\end{array}$ & $\begin{array}{l}\text { Berlin } \\
\text { Univ. of } \\
\text { Technology }\end{array}$ & Rural transport & $\begin{array}{l}\text { The RAMSES on-the-go platform provides an intermodal trip } \\
\text { planner and ticketing for users of rural transportation services, } \\
\text { and specifically aims at empowering small-scale providers of } \\
\text { mobility services in rural areas (e.g. voluntary community } \\
\text { transport providers). }\end{array}$ & $\begin{array}{l}\text { German state of } \\
\text { Baden- } \\
\text { Württemberg }\end{array}$ \\
\hline
\end{tabular}

\section{Conclusions}

This work paper's main purpose is to show whether only an urban environment provides suitable conditions for the successful application of IoT technologies, or it is possible to successfully deploy smart mobility systems for smart land too, as stated by RQ1.

The main conclusion resulting from our report is that different opportunities can have very positive impacts for both smart cities and smart lands: indeed, even if we consider the different levels of population scattering, technological infrastructures, social maturity, and economic opportunities, almost all solutions can be implemented in rural as well as in urban areas. Tables 2, 3, 4, 5 show the results of our evaluation. 
Table 2: IoT apps suitability for planners on rural and urban context

\begin{tabular}{|l|l|}
\hline Applications for Planners & Suitable for context \\
\hline Collection of traveler data & rural and urban \\
\hline Collection of vehicle data & rural and urban \\
\hline Collection of traffic data & rural and urban \\
\hline Collection of air quality data & rural and urban \\
\hline Collection of infrastructure data & More suitable for rural \\
\hline Collection of transfer point data & rural and urban \\
\hline Online services for modelling support & rural and urban \\
\hline
\end{tabular}

Table 3: IoT apps suitability for travellers on rural and urban context

\begin{tabular}{|l|l|}
\hline Applications for Travellers & Suitable for context \\
\hline Real-time service information & rural and urban \\
\hline Co-traveler information & rural and urban \\
\hline Real-time vehicle information & rural and urban \\
\hline Low level service compensation & rural and urban \\
\hline Traveler support & More suitable for rural \\
\hline Collection of transfer point data & rural and urban \\
\hline Enriched travel experience & rural and urban \\
\hline
\end{tabular}

Table 4: IoT apps suitability for operators on rural and urban context

\begin{tabular}{|l|l|}
\hline Applications for Operators & Suitable for context \\
\hline Management of Operations & rural and urban \\
\hline Demand Responsive Transport (DRT) & rural and urban \\
\hline Maintenance-wear & rural and urban \\
\hline Maintenance-damage & rural and urban \\
\hline Self-driving vehicles & rural and urban \\
\hline Transport related services & rural and urban \\
\hline
\end{tabular}

Table 5: Smart mobility issues complexity for urban and rural context

\begin{tabular}{|l|l|}
\hline Issues & Complexity by context \\
\hline Sustainability of the Business Model & Higher for rural \\
\hline Data Privacy and Integrity & same in rural and urban \\
\hline Security & same in rural and urban \\
\hline Interoperability & same in rural and urban \\
\hline Scalability & Higher for urban \\
\hline Usability / Accessibility & Higher for rural \\
\hline Data Collection & Higher for rural \\
\hline
\end{tabular}




\section{Acknowledgements}

Funding for this research was provided by the INTERREG Central Europe project "RUMOBIL."

\section{References}

[1] J. Gubbia, R. Buyyab, S. Marusic, M. Palaniswami, "Internet of Things (IoT): A vision, architectural elements, and future directions," in Future Generation Computer Systems, vol. 29, pp. 1645-1660, 2013.

[2] A. Whitmore, A. Agarwal, L. Da Xu, "The Internet of Things - A survey of topics and trends," in Information Systems Frontiers, vol. 17, no. 2, pp. 261-274, 2015.

[3] A. Zanella, N. Bui, A. Castellani, L. Vangelista, M. Zorzi, "Internet of Things for Smart Cities," in IEEE Internet Things J., vol. 1, pp. 22-32, 2014.

[4] S. Talari, M. Shafie-khah, P. Siano, V. Loia, A. Tommasetti, J. P. S. Catalão, "A Review of Smart Cities Based on the Internet of Things Concept," in Energies, MDPI, 2017.

[5] A. Bonomi, R. Masiero, Dalla smart city alla smart land, Marsilio, 2015.

[6] C. Olaverri-Monreal, "Autonomous Vehicles and Smart Mobility Related Technologies," in Infocommunications Journal, vol. 8, pp. 17-24, 2016.

[7] Methodology and indicator calculation method for sustainable urban mobility. Report produced by the World Business Council for Sustainable Development (WBCSD) as part of its Sustainable Mobility Project 2.0, 2015.

[8] P. Davidsson, B. Hajinasab, J. Holmgren, A. Jevinger, and J. Persson, "The Fourth Wave of Digitalization and Public Transport: Opportunities and Challenges," in Sustainability, MDPI, vol. 8, no. 12, p. 1248, 2016.

[9] B. Kolosz, Grant-Mulle, "Extending cost-benefit analysis for the sustainability impact of inter-urban Intelligent Transport Systems," in Environmental Impact Assessment, Elsevier, Review 50, pp. 167-177, 2015. 